\title{
Размышления генетика о жизни
}

\author{
В.К. Шумный凶
}

Аннотация: В предлагаемой статье автор размышляет о жизни с генетических позиций. Показаны роль генов и условий жизни в формировании личности человека, последствия его ухода из-под естественного отбора. Обозначена роль науки в истории человечества, взаимоотношения науки и политики, науки и религии, охарактеризованы личностные ценности человека в оптимальном варианте. Рассмотрены экологические проблемы, взаимодействие человека с окружающей средой.

Ключевые слова: ген; геном; эволюция; наука; образование; политика; религия; экономика.

Для цитирования: Шумный В.К. Размышления генетика о жизни. Письма в Вавиловский журнал генетики и селекции. 2020;6(2):72-84. DOI 10.18699/Letters2020-6-11

\section{A geneticist's thoughts on life}

\author{
V.K. Shumny凶
}

Abstract: The author reflects on life from a genetic perspective. The role of genes and living conditions in the formation of the human personality, the consequences of human evasion of natural selection are analyzed. The paper provides insights into the part played by science in the history of mankind, relationships between science and politics, science and religion, as well as the optimal personal values. Ecological concerns and human interaction with the environment are considered.

Key words: gene; genome; evolution; science; education; politics; religion; economy.

For citation: Shumny V.K. A geneticist's thoughts on life. Pisma v Vavilovskii Zhurnal Genetiki i Selektsii = Letters to Vavilov Journal of Genetics and Breeding. 2020;6(2):72-84. DOI 10.18699/Letters2020-6-11 (in Russian)

\section{Предисловие. Прогулки по лесу}

Прогулки по Сибирскому лесу наводят на глобальные размышления о жизни, о миссии человечества на планете Земля. Это вполне объяснимо на 87-м году жизни, когда тебя так и тянет поразмышлять о главном и итоговом смысле жизни. Так уж мы устроены, и для общения нам даны речь и письменность, и такой чести удостоен только человек разумный. Прогулки по летнему или зимнему лесу создают особое настроение и активируют мозг вытащить из прошлого яркие и приятные эпизоды бытия. И это настраивает на философское осмысление реальности. Для старейшин это хороший повод осмыслить и оценить прошлое и увидеть в нем положительное и отрицательное и успокоиться, так как это уже прошлое. Это и повод настроиться на безупречное будущее хотя бы виртуально.

Пишущий эти строки рассчитывает на довольно узкий круг читающих и надеется, что некоторые соображения о бытии вызовут интерес. Надежды юношей питают, а стариков тем более. На том и держимся, особенно в сибирском лесу. И чем глубже погружаемся в лес, тем острее возника- ет потребность поразмышлять о смысле жизни. Аналогом этому является поговорка «чем дальше в лес, тем больше дров». В этой поговорке кроется много смыслов, особенно для старейшин. А именно: они и хотят осмыслить свой жизненный путь. Удачи им!

\section{Общие законы жизни}

Жизнь - это реальное прошлое, миг настоящего и ожидаемое будущее. Оцениваем мы наше существование по итогам прошлого, а планируем будущее, иногда не совпадающее с реальностью. Жизнь человека можно сравнить с песочными часами с персональной емкостью, которая определяется генами и условиями жизни примерно в равных долях. Качество генов каждого индивидуума зависит от качества генов родителей. И хотя родителей не выбирают, но знать их родословные крайне желательно.

Наше появление и развитие прописано в геноме химическим текстом из четырех букв. В человеческом геноме этот текст представлен 3 млрд букв, которые упакованы молекулами ДНК в хромосомах. Возникает сакральный вопрос, 
откуда взялась эта самовоспроизводящаяся с колоссальной информационной емкостью молекула, да еще такая умная, давшая начало жизни на Земле. Первый и наиболее обсуждаемый вариант: сформировалась в процессе эволюции жизнь на Земле. Второй вариант: занесена из Космоса, что означает признание внеземных, да еще суперцивилизаций. Размышляя дальше, можем дойти и до Божественного творения. Но мы дальше не пойдем, потому что заблудимся в своих фантазиях, а наука строится на фактах; в данном случае мы их пока накапливаем.

Фридрих Энгельс определил жизнь как «способ существования белковых тел». И он был прав, так как мы действительно в основном состоим из белков. Отсюда простая логическая связка - в геноме (ДНК) записаны программы синтеза белков. И это доказано. Мы примерно знаем, как идет под контролем генома формирование нашего организма и его главного компонента - мозга. Именно он делает человека разумным, в разной степени умным и способным познавать законы природы и по мере накопления этих знаний их использовать. Во всем этом есть простая, но гениальная логика, истоки которой мы тоже пока не вполне понимаем.

У дикой природы главный закон для всех живых систем их эволюция, а более точно, отбор и распространение индивидуумов, более приспособленных по сравнению с другими к условиям внешней среды. Выживает сильнейший. Человек фактически ушел из-под естественного отбора. И лозунг можно дополнить: выживает сильнейший и умнейший. Современный человек - это уже не только эволюционное, но и социальное порождение со всеми вытекающими как положительными, так и отрицательными качествами.

У дикой природы законы более жесткие по сравнению с социальной эволюцией человека. Хотя часто бывает и наоборот. За что боролись дикие животные и наши предки? Прежде всего за территорию, их кормящую. Но борьба шла в основном между видами и крайне редко внутри вида. К сожалению, человек унаследовал гены агрессивности от диких предков и перенес эту борьбу на внутривидовой уровень, открыв тем самым войны между собой. И это трагическая ошибка в истории человечества. И если мы не опомнимся и не прекратим всеобщее сумасшествие, то станем глупыми соучастниками прекращения жизни на планете Земля.

у диких животных сегодня известно три основных типа поведения - агрессивное, спокойное, трусливое. Интенсивно изучается генетика разных типов поведения. К сожалению, и у человека в процессе социальной эволюции наблюдаются все три типа поведения. Особенно настораживает в человеческой популяции наличие агрессивного типа. И это плохо сочетается с великими достижениями человеческого разума. Гены, определяющие агрессивность, мы пока не можем убрать из генома человека, но условиями внешней среды можем скорректировать их проявление и активность. Эти условия определяются уровнем жизни, образованием, воспитанием и примером родителей. Сейчас в генетике есть новое и активно исследуемое направление - редактирование генома. Может, когда-то и научимся исправлять гены нежелательного поведения. Дай-то Бог, поскорее бы!

Сегодня много говорят об искусственном интеллекте. Да, эти умные машины могут взять на себя часть скучных и вредных для человека рабочих процессов и исполнять их даже лучше и быстрее человека. Роботизация производственных процессов крайне важна, так как открывает человеку новые возможности своего развития. Но я считаю, что рано преувеличивать роль искусственного интеллекта в истории человечества и допустить, что искусственный интеллект обеспечит владение миром. Нет, искусственный интеллект будет создан человеком с возможностью его контролировать.

Властелином мира Природа определила человека. И именно его мозг, пока не познанный до конца, рождает наше развитие, включая на данном этапе роботизацию. Хакеры изменили мир, роботы тоже его меняют, а миром владеет и будет владеть человек. И только ему дана речь для общения, и его слово становится всесильным. Природа наградила человека речью и письменностью, для того чтобы он избежал уничтожения себе подобных и чтил святое «Не убий...». Общение и договоренности должны стать основой избежания конфликтов.

К сожалению, человечество всегда недооценивало силу слова и предпочитало силу оружия. Поэтому главнейший вопрос будущего - развитие человеческой личности, наполнение ее идеалами мира, добра и творчества и неукоснительное исполнение хотя бы трех из десяти библейских заповедей: «не убий, не укради, возлюби ближнего своего». И мир станет лучше и безопаснее.

В дореволюционной России представители высших слоев общества, особенно военные, произносили: «Честь имею», что означало: «Отдам жизнь за Отечество, за царябатюшку, а честь никому». Это была вершина достоинства личности, желательно, чтобы и сегодня это звучало почаще. Покушение на честь ранее заканчивалось дуэлью, сегодня скучными дискуссиями - явная девальвация ответственности.

История человечества - это история веры в потусторонние силы, владеющие его судьбой. На этой основе и возникли современные религиозные конфессии, разделившие человеческую популяцию по принадлежности к ним. Но главное во всем этом вера человека. И это сугубо индивидуальное качество, и относиться к этому следует с пониманием и уважением. Сама вера человека уже является его сверхъестественной силой, а ее отсутствие его слабостью. Более подробно об этом далее. Главнейшим критерием развития общества должно быть благополучие личности, ее удовлетворение окружающей действительностью. В естественной природе эволюция, создавшая жизнь на нашей планете, работает не с отдельными особями, а с популяцией разных особей и отбирает наиболее приспособленных к условиям внешней среды. Поэтому очень важно, чтобы популяция представляла максимальное генетическое разнообразие вида растений или животных. Естественный отбор жестко отбраковывает не приспособленных к условиям среды особей. Человек в своей эволюции максимально ушел из-под естественного отбора и начал накапливать в своем геноме нежелательные мутации, часто приводящие к генетическим патологиям. Это плата за уход из-под естественного отбора. Компенсацией этому может быть только мощное развитие медицины. 


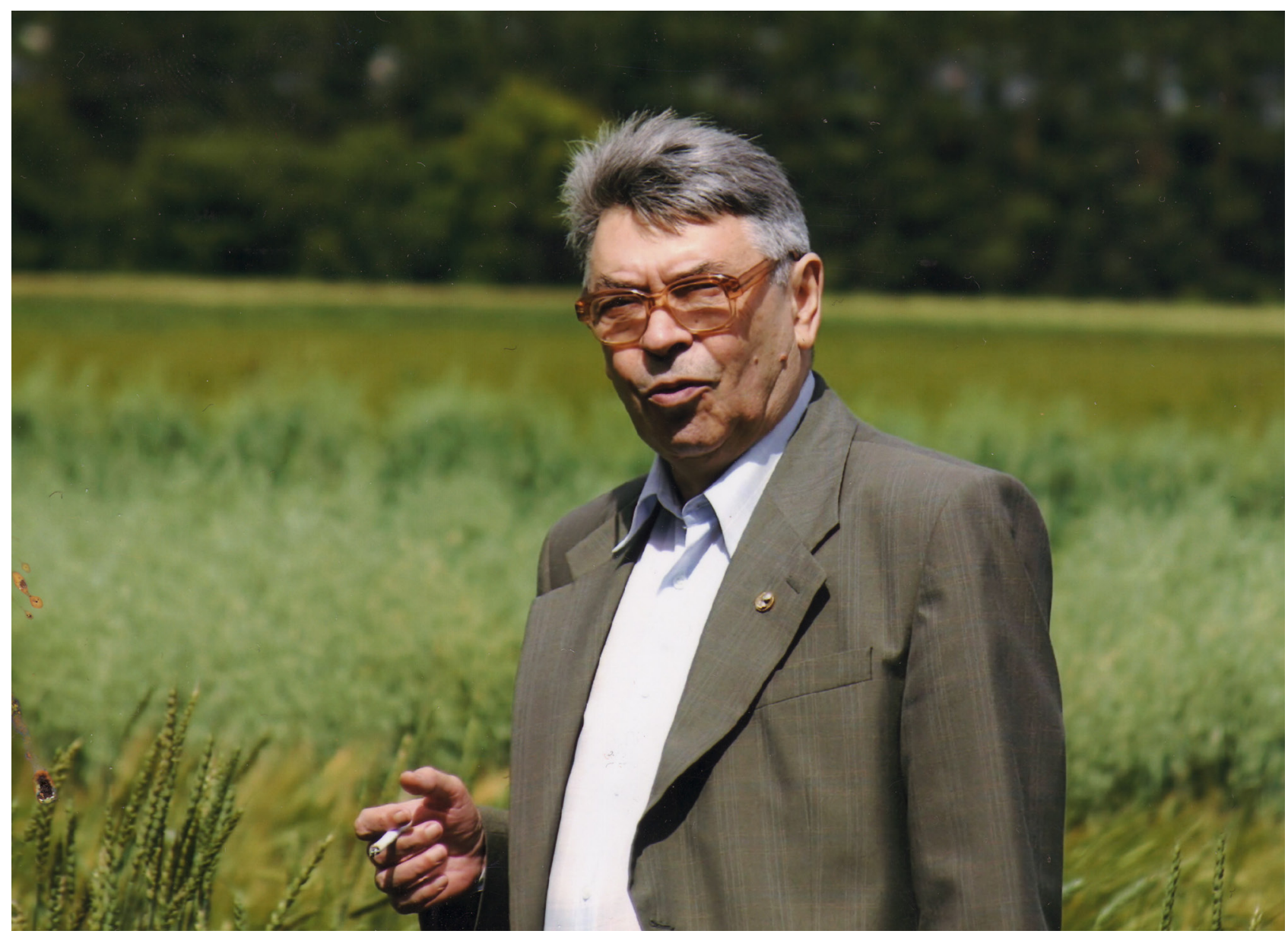

Академик В.К. Шумный, директор ИЦиГ СО РАН (ИЦиГ СО АН СССР) в 1986-2007 гг.

В социальной эволюции человека большое значение имеет преемственность поколений. Новые поколения воспринимают и оценивают для себя моральные и нравственные ценности старших поколений. Это прежде всего права человека, демократические уклады, свобода творчества мысли и слова. Пишущий эти строки уже прожил 57 лет в Советском Союзе и 28 лет в Новой России. Идеологически это были разные периоды в истории нашего Отечества. Не вдаваясь в подробности, отметим, что перечисленные выше ценности современная молодежь пытается превратить в реалии действительности. Мое многолетнее общение со студентами и школьниками свидетельствует, что нам на смену идут очень хорошие, умные и свободомыслящие поколения. Но они другие, сидящие в интернете и часто оппозиционно настроенные к старшим. Мне в свои 86 все труднее спорить с внуками, а тут и правнуки появились. Эти умные и хорошие ребята уже стали продуктом нового научно-технологического уклада, открывающего им пользование огромной информацией по всем направлениям. Они по много часов в сутки торчат в компьютерах и смартфонах.

Мощное конкурентоспособное производство и спрос на потребление выступают основными критериями обдумывания ими экономической стратегии. И это хорошо, что молодежь мыслит такими категориями и выстраивает пока модель системы управления. Она отличается от действующей ныне системы вертикали власти. Поживем - увидим! Главное, что подрастает хорошее поколение на благо России

Формирование полноценного и полезного для общества человека обусловлено многими факторами. Главные из них семья, образование, наследственность и плюс многие другие, но не менее важные. Например, окружающий его социум. Благополучие и счастье человека зависит, как отмечено выше, от того, правильно ли он осознал свое предназначение и в соответствии с этим выбрал профессию. И тогда труд становится созидающим, высокопроизводительным и хорошо оплачиваемым. Именно такая мотивация решает многие существующие проблемы. Какие бы политические и экономические модели мы ни придумывали, на первом месте и в главной роли будет человек, его благополучие, настроение и удовлетворение реальностью. Именно человек решает все сам, и в этом смысл его существования. Лозунг И.В. Сталина «Кадры решают все» чрезмерно прагматичен и ущемляет права личности. Кадры - это уже популяция личностей, отличающихся разнообразием во мнениях и действиях как положительных, так и отрицательных, а нередко и нарушающих права человека, наделенные ему в процессе эволюции живых систем. Жизнь - это реальность личности, ее действий и ничего больше. Остальное - это наше отношение к этому и наши заблуждения и ошибки.

И сегодня очень важно, что преобладает в человеке в 


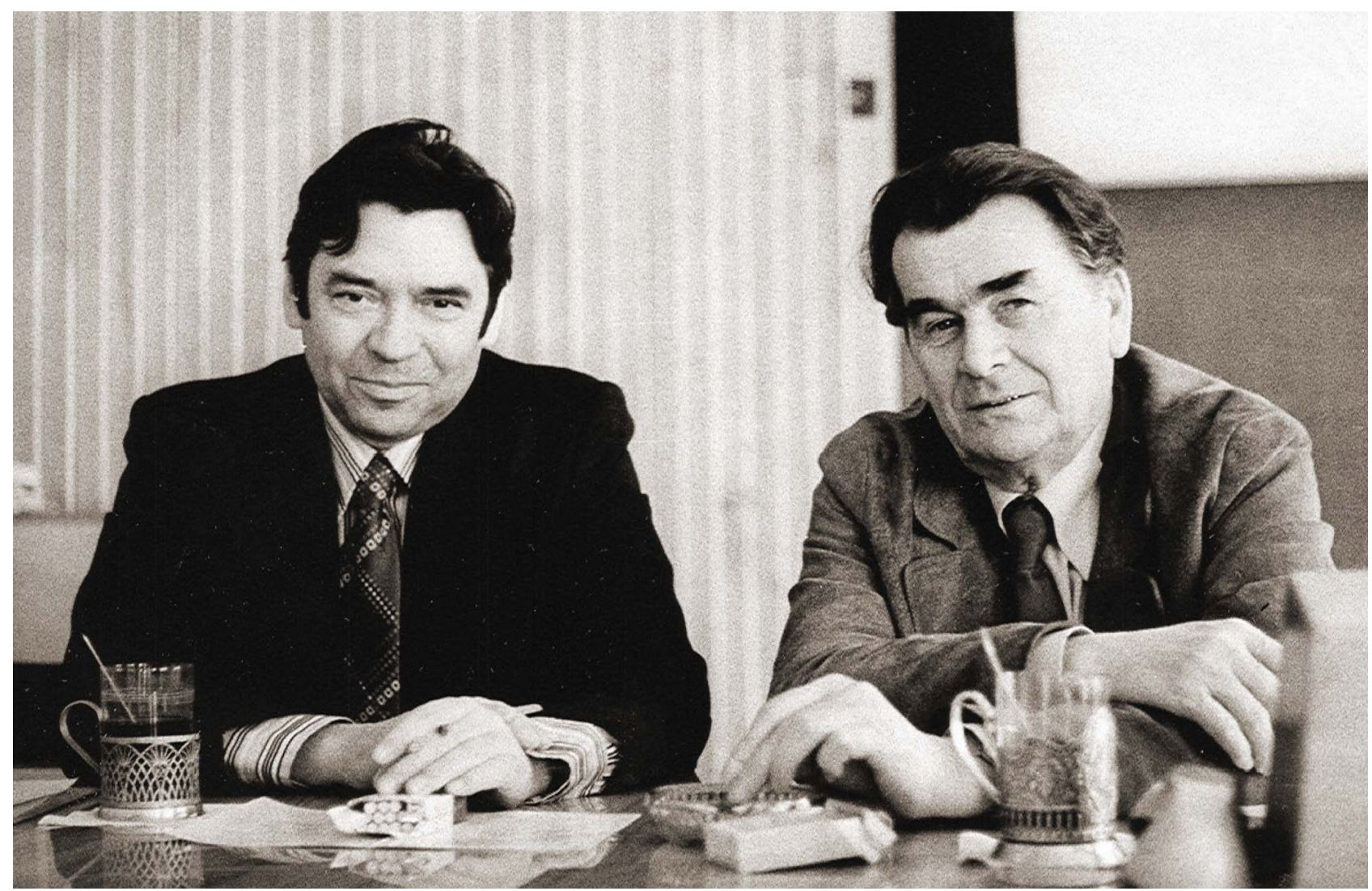

В.К. Шумный (слева) и академик Д.К. Беляев, директор ИЦиГ СО АН СССР в 1959-1985 гг.

будущем - мудрость и доброта или дурость и агрессия. Генетически в человеке заложено и то и другое. Все зависит от того, какие гены в зависимости от условий жизни получат преимущество в своей активности. Поэтому так важна уверенность человека в своем благополучии и адекватном окружении. И из этих мигов между прошлым и будущем и формируется наша жизненная позиция, отношение к ближним по разуму, братьям нашим меньшим, месту рождения, религиозным конфессиям и другим атрибутам нашего существования. Каждая прожитая жизнь - это личная история, из которой и формируется общая история человечества. Но и общая история воспринимается и осмысливается только личностью и только в своем понимании.

Изучая общую историю, человек разделяет ее на положительные, отрицательные и даже трагические моменты, что дает ему основание исключить их из будущего. И в этом сила и смысл истории, а это значит, что ее необходимо знать и, глубоко анализируя, понимать. И только через опыт истории мы сможем выстроить свое положительное будущее. История - это наука о событиях прошлого и осмысление их для будущего.

\section{Наука в истории человечества}

Несколько соображений о роли науки в истории человечества 10-12 тыс. лет тому назад, когда популяция разумных личностей перевалила за 2 млн и они поняли, что пора кончать бегать по лесам, полям и плавать по рекам за добычей пропитания. Второе, что им пришло на ум, - переходить на оседлый образ жизни, самим производить съедобные растения и разводить спокойных к человеку животных. Реализация этих умных мыслей заняла более 10 тыс. лет. Процесс получил научное название "доместикация человеком растений и животных». Это были, пожалуй, первый «научный проект» человека и его первая научная специальность «селекционер». Человек, конечно, понимал, что ему придется иметь дело с дикими видами растений и животных и их преобразованием в культивируемые. Николай Иванович Вавилов определил селекцию «как эволюцию, направляемую волей человека». Эволюция работает на адаптивность к условиям среды, селекция на продуктивность возделываемых видов, что иногда приводит к частичной потере адаптивности. В этом различия и противоречия между эволюцией и селекцией на потребности человека. Первыми доместицированными растениями были зерновые: ячмень и пшеница, позже рис. Это и понятно, так как зерно можно накапливать и долго хранить. Первым доместицированным животным стала собака - верный друг и охранник человека. Основой продовольствия человека стали козы, овцы, свиньи, коровы, лошади. Среди сотен доместицированных растений только 10 видов в основном зерновых составляют до $70 \%$ продовольственного баланса человека, остальные $30 \%$ представлены овощными, фруктовыми, ягодными видами растений. А для радости жизни человек ввел в культуру сотни видов цветочных растений. Такая же картина и с животными, где для радости жизни есть собаки, кошки, птицы и так далее. 


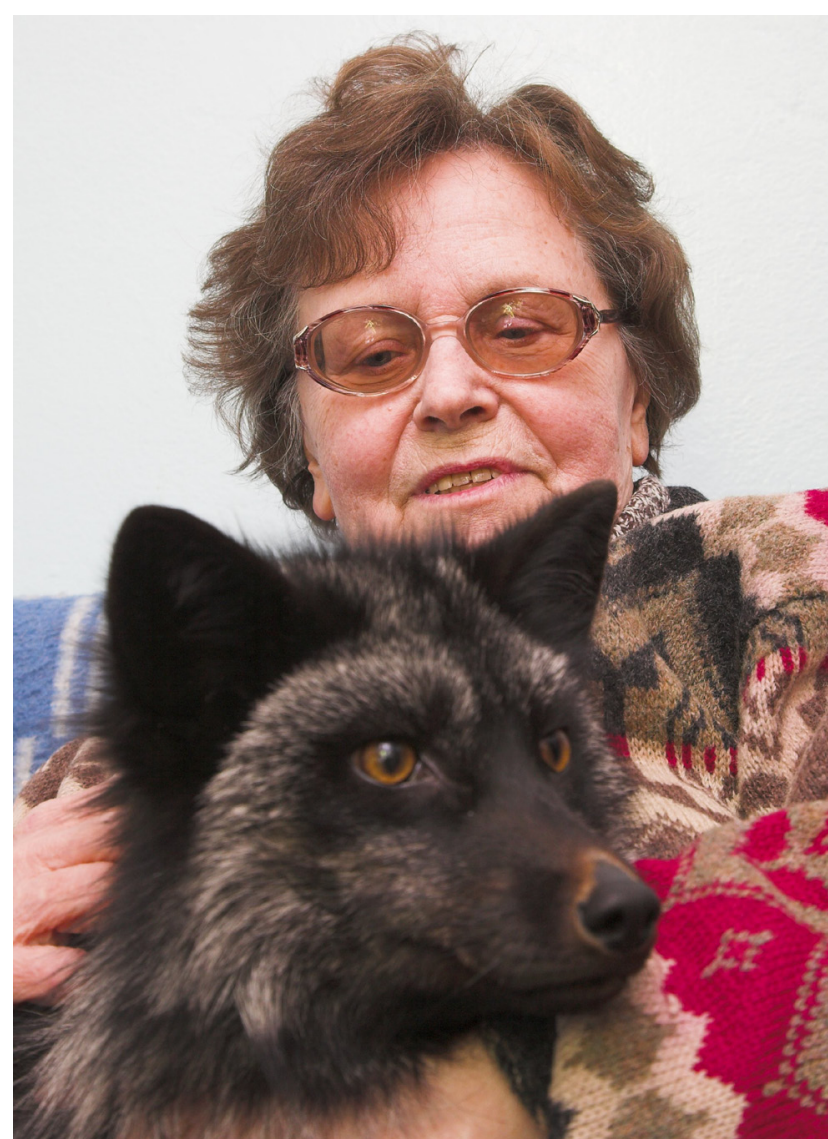

Доктор биологических наук Л.Н. Трут

Возможности доместикации новых видов растений и животных огромны. Тем более это можно сделать быстрее, чем нашим предкам. Эту возможность открыла выдающаяся работа академика Д.К. Беляева, в которой ему и Л.Н. Трут за 50 поколений (50 лет) удалось создать популяцию лисиц, спокойно контактирующих с человеком. Главным критерием отбора было поведение животных. Как отмечено выше, генетикам известно три типа поведения животных - агрессивное, трусливое и спокойное, которых почти 50 поколений и отбирали. Это принесло удачу и всемирную известность работе по доместикации лисиц. Это был самый мощный эксперимент по эволюционной генетике XX века.

Вернемся к истокам наших предков примерно на 10 тыс. лет назад. Переход на оседлый образ жизни - очень важное событие в истории человечества. Человек стал обладателем территории постоянного семейного жилья, что обеспечило рост численности населения. И это заставило его шевелить мозгами и постоянно улучшать производство продовольствия, изобретать орудия для земледелия и условия для содержания животных.

Словосочетание «человек разумный» начало превращаться в дело, творчество, технологии выживания. Здесь возникает и постепенно встает во весь рост новая проблема - защита своей территории и ее постепенное прирастание, а человек наряду с орудиями производства начинает изобретать и орудия защиты и нападения. Таким образом начинает формироваться идеология войн и в ней начинает главенствовать агрессивный тип поведения человека. Как ни печально, но человек в своей истории из охотника на братьев наших меньших с целью своего пропитания превратился в воина для борьбы с такими же человеками, но уже за жизненное пространство и до сих пор остановится не может, изобретая все новые средства уничтожения себе подобных.

Альберт Эйнштейн предупреждал, что если состоится Третья мировая война, то в Четвертой немногие сохранившиеся будут защищаться и нападать с камнями и палками. Не будем забывать, что наш вид называется «человек разумный». Будем надеяться, что у нас не зайдет «ум за разум» и мы не перейдем крайнюю черту к самоуничтожению. С прискорбием приходишь к выводу, что человек - самое опасное из живых существ. Но только ему даны речь, письменность и разум, что вполне достаточно, чтобы в общении договориться о своем будущем. Надежда умирает последней.

Мне на 87-м году жизни стало очень обидно за россиян, за все многонациональные сообщества, проживающие на территории России. Кто-то выделил нам самую северную, самую холодную территорию, две трети из которой вечная мерзлота. Может, мы, как всегда, опоздали на дележку? Не исключено. Складывается впечатление, что опять кто-то же определил Россию экспериментальной площадкой для испытания всех идеологий, систем управления в экстремальных жизненных ситуациях или, как говорят биологи, на провокационных фонах. Для того чтобы доказать, что ты хороший и правильный, для сравнения необходимо рядом иметь нехорошего и неправильного. И для этого наши проблемы в экономике, управлении низким уровнем жизни выбрали Россию, обвиняя ее во всех грехах. Это крайне глупо, но действует. Обидно.

Я уже 62 года живу и работаю в Сибири, не в самых курортных условиях. Но я убежден и по своему опыту знаю, что россияне, имею в виду все национальности и конфессии, очень добрый, умный и отзывчивый народ, прошедший тяжелейшие испытания, но всегда готовый прийти на помощь нуждающимся. И самый живущий в народе и повторяемый всеми поколениями девиз «лишь бы не было войны». Будем надеяться на мудрость Соломона, который на внешней и внутренней части кольца написал: «Все пройдет, и это тоже». Будем надеяться, что мудрость восторжествует. Мы как-то в жизненной суете потеряли страх, а спокойно и равнодушно воспринимаем информацию о локальных конфликтах, забывая исторические факты, что именно они иногда превращаются в злободневные и общемировые. Так было в Первую мировую и во Вторую, которую я уже осознанно воспринимал от первого до последнего дня.

Сегодня главная миссия правящих миром не только не наращивать ядерную мощь, а не менее важная - оградить ядерные кнопки от сумасшедших и сделать все, чтобы заставить гены, определяющие агрессию, замолчать. Многие из этих генов у животных уже известны. Так что генетикам есть над чем работать, но только на животных и думать, как помочь человеку. Запрещено превращать человека в экспериментальный объект. Все, чем мы пользуемся, проходит детальную проверку на созданных для этого линиях экспериментальных животных - мышах, крысах, кроликах, минисвиньях и так далее. 


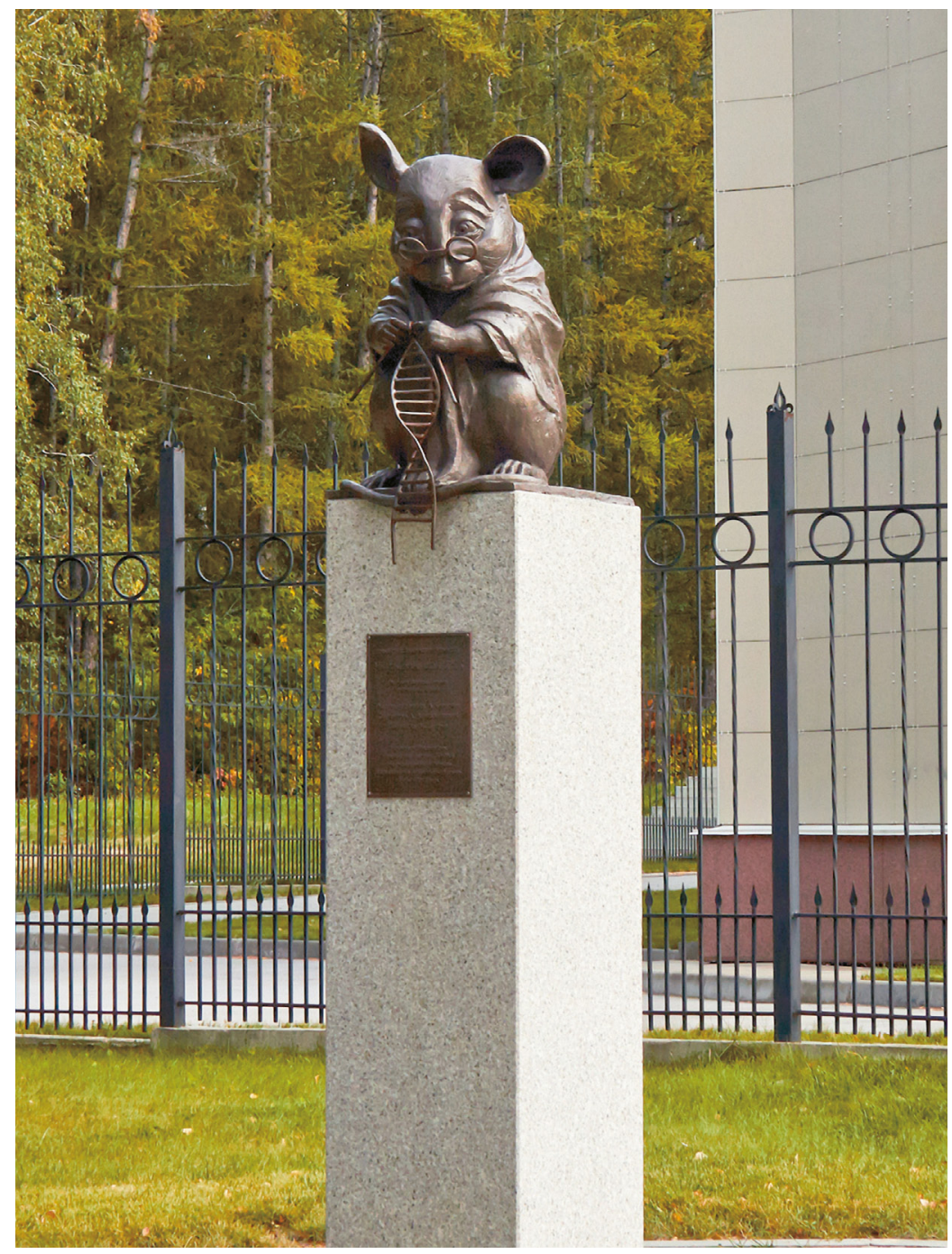

Памятник лабораторной мыши «Мышь, вяжущая ДНК»

Именно эти животные приносят себя в жертву ради человеческого блага. Чтобы хоть как-то отметить этих верных слуг науки, мы возле вивария Института цитологии и генетики поставили памятник мыши, вяжущей молекулу ДНК, и памятник Д.К. Беляеву на скамейке с его любимым объектом - лисичкой, протягивающей ему лапку. Первый памятник своему объекту, собаке, поставил великий физиолог, нобелевский лауреат, академик Иван Петрович Павлов.

Для животных, как и для человека, восприятие жизни возможно только особью или личностью, а вот выживание возможно совокупностью особей или личностей, то есть популяцией. Эволюция работает только с популяциями, и, чем больше в них генетического разнообразия, тем большая вероятность отобрать лучшее и более адаптивное. Возвращаясь к истории человеческой популяции, мы приходим к выводу, что успех ее существования и развития зависит от качества составляющих ее личностей и, прежде всего, от поведенческих характеристик. К качествам человеческой личности следует присоединить ум, честь и совесть. Уже по видовому названию человек разумный должен быть среднестатистически умным. Но в этом смысле важнейшим фак- тором является его самооценка. В человеческой популяции можно встретить личностей, которые считают себя, не будучи таковыми, или гениальными, или глупыми. Гений - очень редкое событие, и его можно или не встретить, или не распознать. Истинно глупых тоже не так много, если учесть, что в основном к ним причисляют себя чрезмерно скромные, и это очень положительное качество. Но большинство «человеков разумных» характеризуется среднестатистическими показателями популяции. Важная деталь самооценки - наличие чувства юмора. Если его нет, то уныние может зашкаливать.

Важнейшие моменты в жизни и благополучии каждого человека - ситуации в семье и трудовом коллективе. Если человек утром с радостью идет на работу, а вечером с такой же радостью идет домой, то это значит, что у него все хорошо и он доволен своим существованием. Это, конечно, идеальная ситуация, но, к сожалению, бывают и другие. Менее благоприятные. Большинство, используя на максимуме свои интеллектуальные и бойцовские качества, меняют ситуацию к лучшему, и это нормально и характерно для человека. Но некоторое меньшинство перестало верить в себя и 


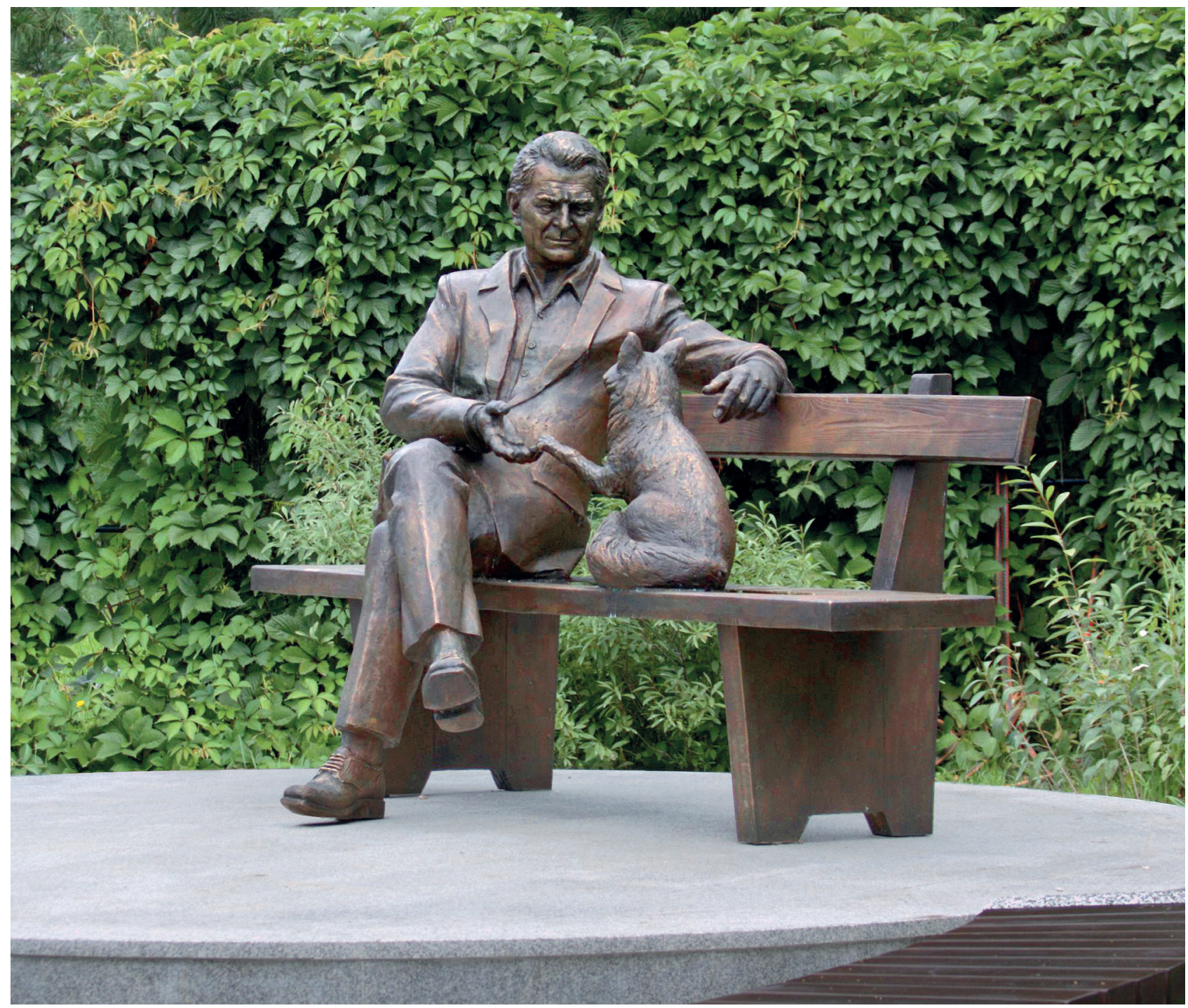

Памятник академику Д.К. Беляеву и его эксперименту по доместикации дикой лисицы

продолжает плыть по течению не сопротивляясь. А жизнь в неверии приводит к потере веры в себя, и это худшее качество человека. И в этой ситуации действенной оказывается помощь его окружающих - родных, близких, друзей и коллег по работе. И ни в коем случае уныние, безнадежность и изоляция. Человек, как ни крути, - стадное животное, и без помощи собратьев ему не выжить. Но собратья должны быть умными и добрыми.

Считается, что семья - первичная ячейка общества. По законам Природы создаются семейные пары, воспроизводящие последующие поколения. Поэтому любовь, на фундаменте которой образуются пары, является основой жизни. Это не изобретение человека, а самый главный закон Природы. Родители нередко настороженно относятся к выбору своих детей. Отсюда и выражения, что «невестки - это не весть что, а зять - что с него взять». Неоспоримо, что по законам Природы миром правит любовь. Но, чтобы любовь и красота спасли мир, к ним обязательно, необходимо добавить взаимопонимание и уважение друг к другу. Если это отсутствует, то даже всесильная любовь даст трещину.
Семья как по материнской, так и по отцовской линии прирастает родственниками и превращается в часть рода, представленного несколькими поколениями. Вот по этой родственной популяции уже можно проследить проявления генов наследования отдельных признаков и предрасположенностей к видам деятельности и, к сожалению, к заболеваниям, в том числе и генетическим, особенно моногенным. Отсюда в высших слоях общества, особенно царствующих династиях, к родословным было особое внимание. Наш царевич Алексей получил ген гемофилии через родственников от царствующей королевы Англии, носительницы этого гена. Это заболевание - удел мальчиков.

Нам всем очень внимательно следует относиться к родословным и знать как можно больше о своих родственниках хотя бы в пяти-семи поколениях.

\section{Человек и наука}

Заниматься наукой - значит, добывать новые знания о законах Природы, мироздания, жизни на планете Земля. Главный мотив входящего в науку - это обостренное любо- 
пытство и способность замечать то, чего не видят другие. Именно отсюда и возникают новые знания об окружающем нас мире. Человек, добывающий новые знания, сообщает о них в своих публикациях, что и формирует их значимость для коллег, а значит, и для науки в целом. Это общемировые схемы научного процесса, который корнями уходит в потребности человека в новых технологиях, улучшающих его жизнь. Как и все в истории человечества, так и в науке главной фигурой считается личность. В научном сообществе роль личности первостепенна. Если личность хорошо определяет стратегию развития своей науки, предлагает новые идеи, то вокруг нее формируется коллектив единомышленников и формируется лаборатория. Для науки это важнейшее структурное звено, и с него все начинается. Руководитель лаборатории определяет направление исследований, их значимость и экспериментальное исполнение. Идеальный вариант, когда лаборатория состоит из генераторов идей и блестящих экспериментаторов, владеющих современными методами. В каждой лаборатории должны быть сотрудники, в деталях знающие изучаемые объекты. Генетически наиболее используемые - плодовая мушка дрозофилы, мыши, крысы, пушные звери, кукуруза, арабидопсис, пшеница, ячмень и другие виды. Все, что делается на животных объектах, в практическом плане экстраполируется на медицину, а значит, и на благо человека. Все, что делается на растительных объектах и на сельскохозяйственных животных, расширяет возможности селекции, а, значит, и решает продовольственную программу, что тоже на благо человека.

В научное сообщество с момента формирования заложены конкурентные взаимоотношения. Каждый борется за известность среди коллег. Некоторым удается стать лидерами в своей науке. Но значительная часть научного сообщества представлена надежными и честными тружениками, которые своим трудом добывают новые знания.

Фундаментальные исследования пополняют наши знания о законах Природы по всем направлениям естественных и гуманитарных наук. Высший уровень фундаментальных знаний необходимо накапливать по всем направлениям естественных наук, так как мы заранее не знаем, где именно произойдет технологический прорыв. Напомним еще раз один пример из истории наших предков. Человек, переходя на оседлый образ жизни, прежде всего обратился к диким видам злаковых растений. Их зерно имеет хорошую питательную ценность, и его можно накапливать и хранить длительное время. Но был один существенный недостаток. Созревая в колосе, зерно осыпалось на почву, откуда его собрать практически было невозможно. Но научное любопытство древних увенчалось успехом. Они нашли среди растений диких злаков те, у которых зерно, созревая, оставалось в колосе. Скорее всего, это были мутации с уплотненными колосковыми чешуйками. И этот, казалось бы, простейший факт сыграл колоссальную роль в судьбе человека, который начал воспроизводить запасы зерна и хранить их на случай неблагоприятных ситуаций.

Среди ученых, проводящих фундаментальные исследования, можно выделить две группы. Для одних фундаментальные исследования - это пополнение новых знаний и предъявление их коллегам в виде публикаций и определе- ния их значимости как для науки, так и для самого исследователя. Другая категория ученых в новых знаниях, кроме сказанного выше, ищет также новые возможности их практического применения во благо человека. Для генетики это получение более продуктивных штаммов промышленных микроорганизмов, новых сортов растений, пород животных, новых генетических технологий, например ДНК-тестов, и многое другое.

Для медицины огромное значение имеет понимание механизмов возникновения генетических заболеваний как моно-, так и полигенных, а еще более важны перспективы их профилактики и лечения. На медицинскую генетику сегодня обращено серьезное внимание научного сообщества. Предстоит очень серьезная и трудная работа в этой области знаний. Что такое геном человека? Это текст из химических букв. Как и в любом тексте, так и в геноме могут быть ошибки. Выпадение букв, их повторение, замена букв, недостающие или излишние знаки препинания и так далее. Печально, что за всем этим следуют тяжелые последствия нашего бытия. Что мы делаем, когда нам в руки попадается плохой текст? Редактируем и улучшаем его. Именно в этом направлении и трудятся сегодня ученые, пытаясь освоить методы редактирования геномов на растениях и лабораторных животных, тем самым приближаясь и к геному человека.

Сегодня очень много говорят, надеются и отрицают возможности искусственного интеллекта, роботизации и цифровизации нашей деятельности. На меня очень сильное впечатление произвел эпизод, когда в Японии нам показали цех одного из заводов, в котором не было рабочих, но все крутилось, вертелось и производило необходимое. Конечно, мы понимали, что за всем этим следят операторы из пунктов управления и при необходимости могут в секунду остановить этот процесс. Но мы понимали и то, что все это изобретено человеком, а значит, ему подконтрольно. Но в истории человечества есть красная линия, которая запрещает переоценивать или недооценивать последствия наших деяний.

\section{Экология}

Законы Природы работают и сохраняют среднестатистические параметры популяций. Резкий уход их в «плюс» или «минус» просто отсекаются, так как это уже выход за красную линию, что крайне опасно. Природа никогда не рискует и тем самым сохраняет эволюционную стабильность. И человек, как разумная часть природы, не должен это делать, чтобы не лишиться будущего. Да и с Природой следует научиться договариваться, понимать ее законы и не нарушать их в своей деятельности. Принципы экологии должны главенствовать в нашей экономике. Прежде всего необходимо категорически запретить сбрасывать в наши реки, озера и прежде всего в Байкал все то, что нам мешает. Мы же закладываем под себя бомбу.

Мы должны напрячь свой ум на решение окружающих нас обыденных экологических проблем и не дать человеку с его мощным естественным интеллектом перейти красную черту с очень серьезными последствиями. Мы и так уже натворили много непотребного для Природы. Она ведь не железная и может не выдержать, а значит, отомстить нам сама того не желая. Все чаще повторяющиеся погодные катаклиз- 


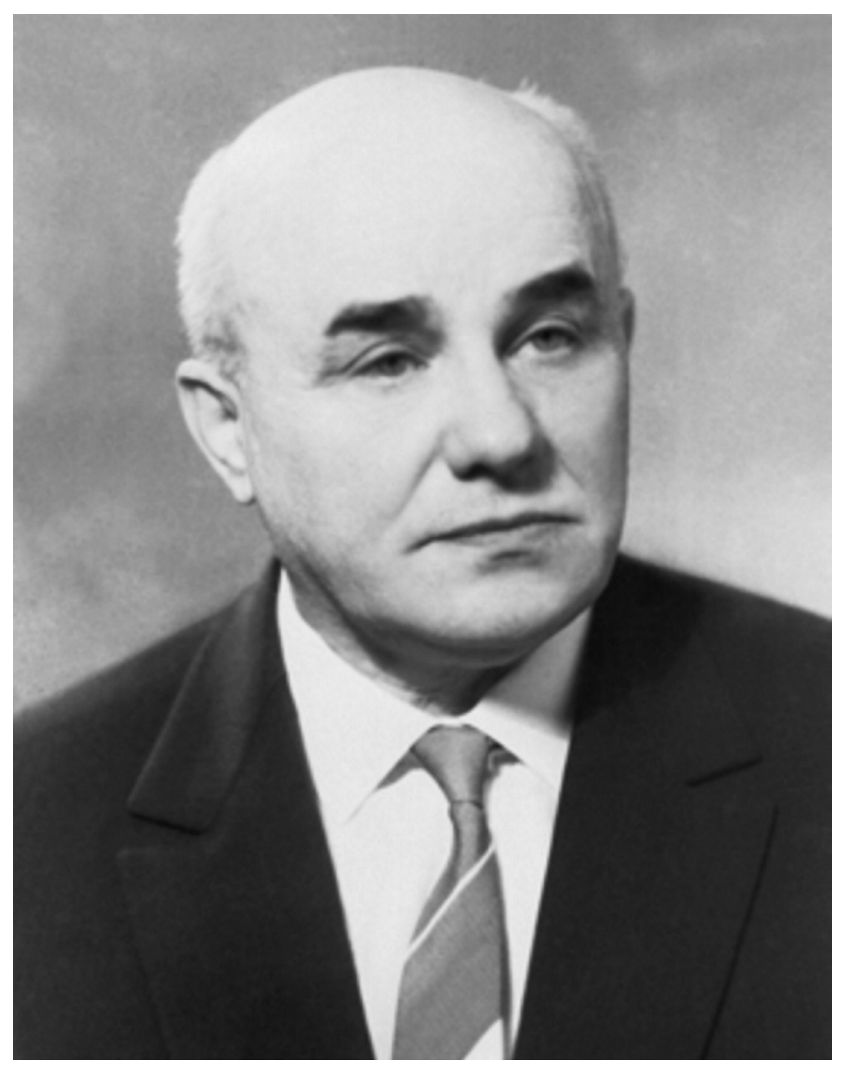

Н.П. Дубинин, директор ИЦиГ СО АН СССР в 1957-1959 гг.

мы должны стать сигналом недооценки их человеком, а значит, нарушением законов Природы.

Если личность по своим параметрам резко отличается от средних для популяции параметрам, то она часто превращается в противовес мнению большинства и перестает с ним считаться. Из таких личностей и формировались профессиональные революционеры, оппозиционеры и другие весьма активные, а иногда и очень агрессивные группы. Меня давно интересует одна из таких активных групп - «зеленые», главной задачей которой является защита Природы. Благородно и положительно. Но иногда их действия и сама идеология защиты Природы вызывают сомнения. Лозунг «не рубить лес», чтобы строить жилье, школы, больницы, университет, для сибиряка-таежника звучит дико. Этот лозунг более понятен для степняков юга России, где действительно необходимо сохранять оставшиеся леса. Для резко различающихся по погодным условиям территориям России должны быть и разные стратегии их обустройства для комфортной жизни человека.

Во время своих зарубежных командировок в Европу, Америку и Азию я интересовался обустройством больших университетских кампусов и был удивлен, что они все окружены великолепными парковыми зонами. По ним можно походить, познакомиться с разнообразием растений, посидеть и великолепно отдохнуть, размяться на спортивных площадках. И я убедился, что именно так следует обустраивать пространство человека. В связи с этим хотелось бы пожелать нашим «зеленым» перейти от запретительных к созданию благоприятных для человека условий.
Конечно, создавать всегда сложнее, чем запрещать. Познав законы Природы человек может вместо ухудшения ситуации значительно улучшить ее, помогая Природе, а значит, и создавать себе более комфортные условия проживания, а для этого необходимо забыть, как уже отмечалось, порочный лозунг «Мы не можем ждать милостей от Природы, взять их у нее - наша задача». Взять-то их можно, но стоить эти милости могут дорого. Природа не подает на милость, она законодатель жизни, а любое нарушение законов наказуемо. Взаимоотношения человека с Природой имеют глобальную значимость.

\section{Пожелания}

Старайтесь как можно раньше определить свою профессиональную нишу, понять, куда больше всего тянет и где вы можете быть максимально полезным: ученым, педагогом, врачом, инженером, токарем, поваром и так далее. Если вы почувствовали, что ошиблись в выборе, то не бойтесь его менять и делайте это как можно раньше и смелее. Если вы выбрали стезю ученого, то должны обладать максимальной любознательностью, повышенным интересом ко всему новому и неизведанному. Чтобы занять в науке достойное место, необходимо получить мощный образовательный фундамент, то есть знать о своей науке все, что сделано до тебя. Да еще свободно владеть английским, чтобы общаться с зарубежными коллегами и читать их работы. Желательно иметь хорошие руки для экспериментальной работы, особенно с живыми объектами. Крайне важно попасть к интересному и уважаемому в научном мире руководителю. От него в значительной мере и зависит ваше будущее в науке.

Мне повезло с научными руководителями. Николай Петрович Дубинин подписал заявление о приеме в Институт цитологии и генетики и сразу определил меня в лабораторию гетерозиса, которой руководил Юрий Петрович Мирюта, выходец из школы Николая Ивановича Вавилова, сохранивший преданность своему учителю в самые трудные времена для генетики. Ниспровергатель устоявшихся догм, бурлящий новыми идеями Юрий Петрович научил нас думать и сомневаться, а главное, сомнения проверять экспериментально. С ним было интересно, но он вскоре уехал в Киев и предложил меня заведующим лабораторией.

Главным своим научным учителем я все-таки считаю Дмитрия Константиновича Беляева, выдающегося эволюциониста, автора эксперимента века по доместикации животных, известного всему мировому биологическому сообществу. Николай Петрович Дубинин пробыл директором Института всего два года и был снят как вейсманист-морганист. Дмитрий Константинович Беляев сменил Н.П. Дубинина и пробыл директором 26 лет. Именно он и сделал Институт таким, каким он сегодня и является. Я довольно рано вошел в команду Д.К. Беляева. Для нас он был примером служения науке, признанным лидером коллектива Института, волевым организатором, патриотом России, прошедшим всю войну от рядового пулеметчика до майора. Сын священника, старший брат Николай, крупный генетик, в 1938 году был репрессирован и погиб. Д.К. Беляев всю жизнь был беспартийным. Рядом с таким человеком было надежно и хотелось максимально ему помогать. 
Умный учитель в школе, в университете, в науке - это залог твоего успеха, фундамент преемственности поколений. Один мудрец сказал: «Если ты видишь дальше других, значит, ты стоишь на плечах гигантов». Думайте и мечтайте, чтобы и ваше поколение в будущем взяло на свои плечи вперед смотрящих учеников. Это будет лучший финал. Все молодые, избравшие накопление знаний смыслом своей жизни, должны понимать, что наука - очень конкурентная сфера деятельности, главным итогом которой становится признание коллег по научному сообществу. Критерии признания жесткие, но все они сводятся к тому, чтобы они были замечены, цитировались и легко воспроизводились. В науке, как в спорте: прыгнул выше всех и становишься известным всей спортивной среде; в науке предложил что-то новенькое и двинулся вверх по рейтинговой лестнице, получая большую известность в научном сообществе. Конкуренция - это движущая сила науки, она работает как естественный отбор в эволюционном процессе, определяя лучших.

С другой стороны, наука - это коллективный труд, когда личности объединяются под новую идею и достигают цели сообща. В этой ситуации переоценивать свою роль в коллективном труде крайне нежелательно. Значимость вашего участия должны определять коллеги. Вся тактика научного поиска решается внутри лабораторий. Если сотрудник считает Институт своим вторым домом, то это высшая оценка деятельности администрации Института. Но успешно работать в дирекции Института могут далеко не все, а только мотивированные на эту деятельность. Это особая категория прирожденных управленцев, которых необходимо разглядеть и уговорить. И главное, чтобы это было положительно воспринято коллективом Института. В противном случае вхождение во власть будет тяжелым.

Я четыре раза избирался директором Института, каждый раз проходя пять этапов тайного голосования. И для меня всегда тайное голосование в коллективе Института было главным показателем. А это были тяжелые годы перестройки и девяностые, когда речь шла о выживании, сохранении институтов и Сибирского отделения РАН. В эти тяжелые годы в СО РАН сформировался мощный директорский корпус из учеников основателей Сибирского отделения, который и взял на себя всю тяжесть ситуации и сохранил науку в Сибири. И все же я не советую начинающим научную карьеру стремиться к административным должностям. Лучший вариант - четко определить свое направление в науке, найти свободную или мало занятую нишу, собрать вокруг себя единомышленников и в раскладе по максимуму создать и возглавить лабораторию. Для ученых - это верх стремлений. И удачи вам всем на этом тернистом пути. Будут и неудачи, воспринимайте их спокойно, как данность.

Вернемся к структуре научного сообщества, которая представляет собой хотя и небольшую, но тоже глобально значимую часть человеческой популяции. Выше мы рассмотрели очень важную структуру - лабораторию, где научным лидером является заведующий, а ниже несколько разных по функциям групп исполнителей. Лаборатории - главные структурные единицы научно-исследовательского Института, во главе которого стоит директор. Его задача - выработка общей стратегии развития Института, всех его направлений и лабораторий. И, естественно, мечта каждого директора сделать свой Институт известным всему научному сообществу по определенному направлению. Не менее важно для директора найти для Института свою нишу, где он может стать лидером.

Поднимаемся выше. Есть лидеры, которых научное сообщество независимо от занимаемой ими должности знает поименно и чтит как основателей новых направлений в науке. Многие из них становятся лауреатами Нобелевской премии. Для генетики это прежде всего Грегор Мендель, открывший гены, и Томас Морган, создавший хромосомную теорию наследственности и получивший за нее первую Нобелевскую премию по генетике. Г. Мендель - это середина XIX века, Т. Морган - первая половина XX века.

Российскую генетическую школу, очень сильную и общепризнанную, сформировали в первой половине XX века профессора Ю.А. Филипченко и Н.И. Вавилов в Ленинграде, Н.К. Кольцов, А.С. Серебровский, Н.П. Дубинин и их коллеги в Москве. Факт, что судьба многих была необычайно сложной, многие коллеги их не понимали, а значит, и не признавали. Так, открытие генов и начало развития новой генетики Г. Менделем было понято и признано только через 30 лет после публикации его статьи, когда первооткрыватель уже ушел из жизни. Такое в науке бывает часто.

Иногда первооткрыватель при публикации результатов своих исследований обращает внимание на отдельные детали, которые для остальных коллег кажутся второстепенными. Но часто именно они становятся основой открытий. Скептики потом удивляются, что действительно все гениальное просто. На этом принципе и сложились законы Природы. Все живые системы созданы по единому принципу с сохранением видовой специфики, механизмов генетического разнообразия и эволюции на адаптивность к внешним условиям. Мудрость Природы в данном случае - унификация процессов жизни.

\section{Наука и политика}

Наука интернациональна, она не имеет государственных границ. Это относится прежде всего к фундаментальным исследованиям, к накоплению новых знаний. Поддержка государством уровня и качества фундаментальных исследований оценивается по международным стандартам, по уровню признания мировым научным сообществом, по целому ряду критериев - публикации, их цитирование, рейтинг журналов и так далее. Отношение ученых к политике определяется простыми критериями - государство должно поддерживать науку, обеспечивать ее развитие, свободу поиска и международное сотрудничество. Во внутренней политике страны для ученых простой критерий обеспечивать и улучшать благосостояние своих граждан. Для большинства ученых позывы к активной политической деятельности отсутствуют. Ученые, в большинстве технари и прагматики, прекрасно знают, что все условия для этого у нас есть, а наши неудачи - результат плохого и неквалифицированного исполнения и малая ответственность за это.

Президент должен выстроить стратегию развития России, а мы его нагружаем починкой крыш, ремонтом дорог, плохой медициной в деревнях и поселках и многим другим. 
Переход на ручное управление - это большой изъян вертикали власти, который многократно усиливается по горизонтали в регионах. Вертикаль власти, на мой взгляд, должна работать не только сверху вниз, но и наоборот, отбирая лучших управленцев в промышленности, сельском хозяйстве, бизнесе и обеспечивая им продвижение вверх по служебной лестнице. Назначения на ответственные должности обязательно должны быть связаны с уже успешным опытом работы на производстве, а не с желанием получить власть. Власть следует давать не тем, кто ее желает, а тем, кого придется долго уговаривать получить ее. Мой многолетний директорский опыт крупного НИИ подтверждает это. Власть любого уровня - это служение подчиненным, их интересам и их благополучию. Для всех входящих во власть это должно быть законом.

Среди ученых, хотя и очень редко, встречаются личности, предрасположенные к политической деятельности и желающие активно в ней участвовать. Но большинство ученых считают наиболее адекватным вариантом для себя нейтральное отношение к политике. Положительное или отрицательное отношение к ней зависит от отношения государства к науке, уровня ее поддержки и понимания роли науки в развитии государства. Одним из отрицательных моментов в научно-технической политике России является отсутствие четкой системы управления этим процессом.

Раньше головной научной организацией была Академия наук с ее институтами, отвечающая за фундаментальные исследования. Госкомитет по науке и технике в СССР отвечал и поддерживал прикладные исследования. Академическая система организации науки успешно работает в России почти 300 лет. В 2012 году произошли серьезные изменения в управлении наукой. Все институты РАН подчинены Министерству науки и высшего образования и обязаны выполнять все министерские требования и регламенты. Российская академия наук состоит из членов академии, их общего собрания и Президиума как исполнительного органа. По всем направлениям наук сохранились специализированные отделения, состоящие из членов РАН. Главная задача Академии наук - экспертное сопровождение значимых для России научно-технических проектов. Довольно неопределенное и расплывчатое предназначение. Важным и нерешенным вопросом реформы РАН является отсутствие главного и единого ответчика, идеолога и разработчика стратегии развития науки в России и оценки результатов, проводимых фундаментальных и прикладных исследований. Раньше за все отвечала Академия наук СССР, а затем Российская академия наук.

Сегодня это прежде всего Министерство науки и высшего образования по согласованию с Академией наук. Был предложен даже принцип «двух ключей» для решения всех проблем науки. Для этого в состав РАН в виде отделений были введены академии медицинских и сельскохозяйственных наук. Но все это было плохо продумано и не нашло реализации. Один из двух ключей так и остается лежать под ковриком перед входной дверью. Таким образом, важнейшие вопросы управления наукой остаются до сих пор в подвешенном состоянии. Утешает то, что академические институты, несмотря на переподчиненность, объединения в федеральные центры, работают в прежнем режиме, хотя и ворчат на увеличение пресса формальных требований со стороны Министерства. Породить проблемы легко, а решить их потом бывает очень трудно.

И в этом случае наука, как интернациональное достояние, тесно связана с политикой государства по отношению $\mathrm{K}$ ней. И, естественно, она надеется на понимание ее проблем и помощь в их решении. Есть сферы государственной деятельности, где резкие изменения, смелые эксперименты, плохо продуманные реформы весьма опасны. Это прежде всего образование, наука и медицина.

Невозможно понять, зачем прекрасно выстроенное среднее школьное образование и высшее в виде пятилетней специализации заменили на ЕГЭ и Болонскую систему. Возможно, эти системы создавались для тех стран, где существуют совершенно другие подходы подготовки школьников к поступлению в университет. У нас же при поступлении в вузы оценивались школьные знания, уровень которых рейтинговался на вступительных экзаменах, и было ясно, что успешно сдавшие его имеют все основания успешно за 5 лет освоить предлагаемый им объем знаний и получить диплом о высшем образовании. Все понимают, кто такой инженер, врач, учитель, агроном. Но для многих не совсем понятно, кто такие бакалавры и магистры. Перемудрили инициаторы реформ, а может, перестарались. Младореформаторы зачастую бывают очень амбициозными. А иначе как их запомнить.

Однажды я спросил у друга, академика, мнение о его успешном ученике и получил неожиданный ответ: «Огонь и воды прошел успешно, а вот медные трубы не смог». Бывает и такое. Еще раз убеждаюсь в том, что во власть следует пускать не жаждущих, а тех, кто способен ее употребить во благо. Мы никогда не задумываемся над тем, какое многоликое, генетическое разнообразие личностей имеется, потому что они неожиданно проявляются иногда только в экстремальных ситуациях и часто к нашему удивлению.

Политика для человека - это атрибут власти, по законам которой он существует. Но у человека есть и внешнее предназначение - он дитя Природы и должен знать, уважать, не нарушать прежде всего ее законы. И раз уж по воле случая тебе выпала такая честь получить земную жизнь, то и постарайся пройти ее с минимальными отступлениями от общечеловеческих заповедей.

\section{Наука и религия}

Наука - это существенная часть государства, создающая материальные блага для человека в виде новых технологий во всех сферах экономики. Религия отделена от государства и представляет духовную сферу личности, ее веру в Бога и бессмертие души человека. Главным стержнем духовности личности является вера в жизнь, в доброту, справедливость и во Всевышнего, обладающего всеми этими качествами и управляющего судьбой человека. Это особенно ярко видно, когда человек попадает в тяжелую ситуацию и окружающие его ничем не могут ему помочь. В такой ситуации остается обращение к Богу и вера в его помощь, в ожидании которой становится легче. Этим и измеряется сила веры человека как важнейшего фактора в его судьбе. И это заслуживает уважения. 
Часть человеческой популяции считает себя атеистами, отрицающими существование Бога и веру в него. Это их личная позиция, и к их неверию тоже следует относиться спокойно и уважительно.

Главный религиозный постулат - это бессмертие души человеческой, ее уход из бренного тела в неземную жизнь. Вот только понять бы, что такое душа. Не только знаний, но даже фантазий не хватает, чтобы понять это. Но генетики проблему бессмертия объясняют научно и просто: никуда не исчезают, а передаются из поколения в поколение наши гены и именно они и являются элементом, единицей бессмертия. Половые клетки родителей содержат молекулы ДНК с нашими генами, образуют одноклеточный зародыш, который развивается до личности по программе, записанной в генах.

Главная задача ученого - выстраивать свое мировоззрение на основе добытых знаний и достоверных фактов. Все это он делает для блага человека, для улучшения условий его земной жизни.

Главная задача священника связана с духовной сферой человека, его верой в существование Бога и его всесилии над судьбой человека. Правила же земной жизни верующего человека заложены в десяти заповедях нагорной проповеди - «не убий», «не укради» и других.

Поэтому наука и религия не являются противостоящими идеологиями, у них совершенно разные задачи и сферы деятельности. Они по-разному видят судьбу человека и по-разному оценивают его веру в Бога. Хотя не исключено совмещение в одном лице ученого и верующего человека. Такие случаи я наблюдаю и ничего плохого в них не вижу. Человек имеет право на свободу выбора. Яркий пример этому - великий физиолог, Нобелевский лауреат, академик Иван Петрович Павлов. Высшие слои общества во всем мире воспринимают веру в Бога как веру в высшую справедливость и всегда противостояли грубым вмешательствам в дела религиозные. Некоторые президенты заканчивают свои речи словами «С нами Бог!» Но все-таки это внешнее проявление веры. А есть молчаливое, но более глубокое проявление веры - внутреннее, а значит, личное. И именно оно и есть настоящая вера. Ведь верить необходимо прежде всего в самого себя, в избранные тобой идеалы, в доброту, справедливость и равенство и благие намерения человека разумного.

Вера и разум сделали человека властелином планеты Земля и возложили на него полную ответственность за ее благополучие. Блажен, кто верует. И прежде всего в самого себя. Это делает человека сильным, а безверие - слабым. Главное, чтобы цели и их мотивы были добрыми и полезными всему человеческому сообществу. Это и есть наше главное предназначение в земной жизни.

\section{Итого}

Что необходимо человеку?

Во-первых, получить жизнь, то есть родиться на планете Земля и стать членом стаи, обладающей разумом живых существ.

Во-вторых, заполучить хороших, добрых, справедливых и любящих родителей и получить от них прививку делать в будущем только благо для окружающих тебя собратьев, в том числе и меньших.

В-третьих, как можно раньше предугадать свое предназначение и по нему определить род своей деятельности, то есть профессию. По избранному роду деятельности желательно получить максимально полное образование и стать не просто, а экстра-специалистом.

Для полного счастья человек не должен замыкаться в узкопрофессиональной деятельности и должен для себя и окружающих быть знатоком литературы, поэзии, музыки, живописи, спорта, еще многого и интересного для общения. Лично для меня особый интерес для общения представляет человек, который хорошо знает историю и с которым можно поспорить по оценке известных в прошлом событий.

По христианским канонам, одним из самых тяжких грехов человека считается уныние. Сегодня мы называем его депрессией, стрессом. Это очень мощные факторы воздействия на организм человека, так как они ослабляют его устойчивость, иммунитет к воздействию внешних факторов и часто становятся причиной различного рода заболеваний, изменения поведенческих и психоэмоциональных проявлений. За свою жизнь человек подвержен многим стрессам, но он обязан пополнять резервы, позволяющие спокойно и быстро избавляться от них. Для этого понадобится мощная поддержка родных, близких и друзей, так как в одиночестве сделать это бывает гораздо тяжелее, а иногда и невозможно.

Уход в себя ничего хорошего не предвещает. Организм человека обладает огромными возможностями и иногда в экстремальных ситуациях творит чудеса. Но главное в том, чтобы правильно распределить эти возможности в процессе жизни и пореже выходить в экстремальные ситуации.

Во всем следует соблюдать меру. Выше я писал, что Природа любит, когда все параметры в пределах средней по популяции. Выпендреж не поддерживается, хотя в редких случаях он полезен.

Более привлекателен для окружающих человек, обладающий чувством юмора. Это особенно важно по отношению к себе и своей самооценке. Именно чувство юмора помогает человеку справиться с унынием, депрессией, а в целом и со стрессом. Но юмор должен быть добрый, вызывающий успокоение и веселое настроение и, конечно, без обид.

Отмечено, что в самые трудные времена появляется много анекдотов. Это прием самозащиты: юмор помогает справиться с трудностями. До сих пор народ веселится, вспоминая В.С. Черномырдина с его «хотели как лучше, а получилось как всегда». Человеку ведь требуется хорошее настроение, которое и создается его отношением к юмору.

Матушка Природа запрограммировала человеку, да и всем живым существам жизненный цикл и его главный итог - воспроизведение последующих поколений и продолжение рода в детях, внуках и далее. Все, что человек делает помимо этого, связано с необходимостью поставить новые поколения на ноги и обеспечить им лучшее будущее. И для этого человек в процессе своего жизненного цикла старается сделать все максимально продуктивно. Для этого он и создан Природой. Гениально решена и вторая задача - равное количество мужчин и женщин во всех поколениях, 50:50 
с небольшими отклонениями. Это определяют две половые хромосомы X и Y (XX - женщина, XY - мужчина). При этом пол всегда определяет мужчина. Итогом всего этого является подбор пар - создание семьи. Генетический итог - перекомбинация генов родителей в геноме детей и на выходе новых сочетаний генов и на их основе биоразнообразие потомков, что так необходимо для эволюции.

И все это значит, что человеку необходима надежная и прочная семья. Но основа ее создания весьма непроста. Принято считать, что любовь и красота спасут мир, и с этим можно согласиться. Хотя Николай Васильевич Гоголь считал, что нет чувства выше товарищества, и с этим можно тоже согласиться. И тогда получается, что для прочной семьи нужна триада - любовь, взаимное уважение и товарищи по жизни. Иначе может не получиться. Как говорят, «жизнь прожить не поле перейти». Все бывает: ошибки, нелучшие поступки, о которых сожалеешь. И если человек это осознает, то следует научиться прощать его.

Самоутверждаться нужно спокойно и с полным пониманием темы обсуждения. Если не уверен, лучше воспользоваться поговоркой англичан «не упусти случая промолчать». Это касается прежде всего эмоциональных личностей. Необходимо научиться с раннего возраста уважать старших. У некоторых национальностей это святой закон. И сделать так, чтобы это стало всеобщим достоянием. Это важно по многим причинам. Это преемственность поколений, это огромный жизненный опыт, это мудрость в принятии решений, это научные школы, объединяющие многие поколения, во главе которых стоят старейшины.

Уважение старших - это понимание прошлого, на котором и выстраивается наше настоящее и будущее. Количество людей, не помнящих родства, должно постоянно уменьшаться. Человек во всех ситуациях должен оставаться оптимистом, быть уверенным в своих силах и знать, что он способен преодолеть любые трудности. Необходимо научиться адекватно справляться со стрессами и ни в коем случае не впадать в депрессию. Для человека это очень опасно, в том числе и для здоровья. Иногда у человека в процессе его жизни возникают негативные поведенческие реакции: повышенная агрессивность, злобливость, излишняя прямота, дерзость, грубость, трусость. Это, к сожалению, связано с перекомбинацией родительских генов, формированием их новых сочетаний. Их проявление обусловлено неблагоприятными условиями жизни. Важно как можно раньше их заметить и через воспитание и образование максимально смягчить.

Как советуют, не смешите Всевышнего своими планами на будущее. Лучше сохраните надежду, что в ваших песочных часах жизни еще есть содержимое.

Конфликт интересов. Автор заявляет об отсутствии конфликта интересов.

Поступила в редакцию 02.04.2020. После рецензирования 28.04.2020. Принята к публикации 28.04.2020. 